\title{
Chemotactic Factor Inactivator in Normal Human Serum
}

\author{
Jeffrey L. Berenberg and Peter A. Ward \\ From the Walter Reed Army Institute of Research, Washington, D. C. 20012 \\ and the Department of Pathology, The University of Connecticut Health \\ Center, Farmington, Connecticut 06032
}

\begin{abstract}
A B S T R A C T Normal human serum contains an inactivator of chemotactic factors for neutrophilic leukocytes. The chemotactic factor inactivator (CF-I) remains soluble when serum is fractionated with ammonium sulfate (at $45 \%$ saturation), directly and irreversibly inactivates chemotactic factors, and it has a broad spectrum of activity as indicated by its inactivation of the chemotactic fragments of human $\mathrm{C} 3$ and $\mathrm{C} 5$ (third and fifth components of complement), $\mathrm{C} \overline{567}$, and the bacterial chemotactic factor derived from Escherichia coli. CF-I appears as a biphasic activity according to preparative techniques of sucrose density ultracentrifugation, electrophoresis, and gel filtration. Studies on the interaction of CF-I with the radiotagged C5 chemotactic fragment fail to reveal evidence for irreversible binding as the basis for inactivation. CF-I varies from the anaphylatoxin inactivator in several physical-chemical respects, but evidence does not permit a conclusive statement about the relationship of the two inactivators. CF-I may function as a regulator of inflammatory responses.
\end{abstract}

\section{INTRODUCTION}

The acute inflammatory response is mediated by a variety of factors which either increase vascular permeability or lead to the leukotactic accumulation of neutrophils. The mediators themselves are chemically diverse, ranging from peptides (the kinins, anaphylatoxins, and chemotactic factors) to substances of very low $(<1,000)$ molecular weight (e.g. the vasoactive amines). As typified by the complement-derived leukotactic factors (from the third, C3, and fifth, C5 components of complement), a diversity exists not only in structure but also in the generation of these inflammatory mediators. For example, $\mathrm{C} 3$ and $\mathrm{C} 5$ can be cleaved productive of anaphylatoxin and leukotactic fragments not only by enzymes intrinsic to the complement system, but also by

Received for publication 22 August 1972 and in revised form 26 October 1972. enzymes extrinsic to complement, such as plasmin, trypsin, thrombin, and tissue derived neutral proteases (reviewed in 1).

In spite of the remarkable diversity of mediators, the inflammatory response is kept in balance by naturally occurring inhibitors. For instance, the kinins and the anaphylatoxins are destroyed almost immediately upon generation in serum. This phenomenon of inactivation has been related to the existence in serum of a carboxypeptidase $B$ enzyme that inactivates the kinins and the anaphylatoxins by removal of the $\mathrm{C}$-terminal arginine residue in the peptides (2). In this report we describe the presence in normal human serum of a chemotactic factor inactivator. It seems likely that the function of this inactivator is to provide regulatory control over the leukotactic mediators generated in serum.

\section{METHODS}

Chemotactic assays. Chemotaxis was performed by the micropore filter technique in modified Boyden chambers. This technique has been previously described in detail $(3,4)$. Filters of $0.65 \mu \mathrm{m}$ pore size (Millipore Corp., Bedford, Mass.) were used and chemotactic activity quantitated by counting the numbers of cells which had migrated through channels of filters in five high power fields under light microscopy. Rabbit neutrophils from glycogen-induced peritoneal exudates were the indicator cells. The upper compartment of each chemotaxis chamber contained a total of $2.5 \times 10^{8}$ neutrophils in $0.1 \%$ bovine serum albumin (BSA). The bottom compartment of each chamber contained the fluids to be tested for chemotactic activity. Hank's medium (Microbiological Associates, Inc., Bethesda, Md.) was used for dilution of both cells and fluids. For convenience, rabbit neutrophils were the usual indicator cell. However, the results tested in Tables I, II, and IV were reproduced using human neutrophils as the indicator cells. Only the data obtained with rabbit neutrophils are listed in this report.

In all cases where studies of the chemotactic factor were carried out, the chemotactic factor inactivator was mixed with $50 \mu 1$ Escherichia coli bacterial factor (see below) or other chemotactic factors, as indicated. After incubation at room temperature for $30 \mathrm{~min}$, this mixture was adjusted to $1.0 \mathrm{ml}$ with Hank's medium and the chemotactic assay carried out. Per cent inhibition was determined by calculat- 
ing the ratio of chemotactic activity in the presence of the inactivator and in its absence, times 100 and subtracting from 100 .

Preparation of chemotactic bacteria: bacterial factor was obtained from culture supernatants (in Hank's medium) of E. coli sterilized by filtration through a Micropore filter (5). $50 \mu \mathrm{l}$ of this factor were used as the standard source of chemotactic factor unless otherwise indicated.

Preparation of complement chemotactic factors. Human C3 and C5 were purified according to the method of Nilsson and Müller-Eberhard (6), which included a combination of isoelectric precipitation, ion exchange chromatography, hydroxyl apatite chromatography, and preparative electrophoresis. Chemotactic fragments of $\mathrm{C} 3$ were produced by treatment with trypsin (Mann Research Labs., Inc., New York) according to the procedure of Bokisch and MüllerEberhard (2). Chemotactic fragments of C5 were obtained in a similar manner (7). Except where indicated, these solutions were not fractionated further. In one experiment $1 \mathrm{mg}$ unlabeled $\mathrm{C} 5$, mixed with $0.1 \mathrm{mg}$ radiotagged C5 (by the iodine monochloride method, 12), was treated with 100 $\mu \mathrm{g}$ trypsin (in a reaction volume of $0.5 \mathrm{ml}$ ) at $32^{\circ} \mathrm{C} \times 20$ $\mathrm{min}$. The reaction was stopped by addition of $200 \mu \mathrm{g}$ soybean trypsin inhibitor (Mann Research Labs., Inc.) contained in a volume of $50 \mu \mathrm{l}$ in phosphate-buffered saline. The trypsinized (and chemotactically active) C5 material was then fractionated by gel filtration, as described below. A zone of radioactivity near the void volume of the eluted column was found, as well as one near the cytochrome marker. The radioactivity in the latter zone was pooled and used as the source of chemotactically active $\mathrm{C} 5$ fragment (7). Human C $\overline{567}$, activated by trypsin treatment of C567 (8), was kindly provided by Doctors C. Arroyave and H. J. Müller-Eberhard.

Preparative electrophorcsis. Human serum was dialyzed for $12 \mathrm{~h}$ against barbital buffer, $\mathrm{pH} 8.6$, ionic strength 0.05 . Pevikon block electrophoresis was then carried out in the same buffer for $18 \mathrm{~h}$ (9). The resulting fractions were

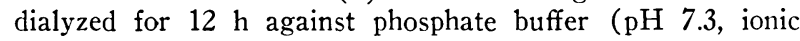

TABLE I

Presence of Chemotactic Factor Inactirator in Serum Fractions

\begin{tabular}{lccc}
\hline Source of inactivator* & $\begin{array}{c}\text { Volume of } \\
\text { inactivator } \\
\text { used } \ddagger\end{array}$ & $\begin{array}{c}\text { Chemotactic } \$ \\
\text { activity }\end{array}$ & Inhibition \\
\hline J. D., whole serum & $\mu l$ & & $\%$ \\
J. D., supernate & 100 & 210 & 9 \\
J. D., precipitate & 150 & 15 & 97 \\
K. J., supernate & 300 & 200 & 9 \\
K. J., precipitate & 300 & 20 & 91 \\
None\| & 300 & 195 & 10 \\
\hline
\end{tabular}

* $50 \mu$ l chemotactic factors from $E$. coli used. Initials refer to serum donors. Fractions of serum obtained by ammonium sulfate at $45 \%$ saturation were employed. See text.

$\ddagger$ None of these preparations were chemotactically active by themselves.

$\S$ Number of migrated cells in five high power fields, as in reference 3 .

|| Background chemotactic activity (in absence of bacterial chemotactic factor) : count of 20 .
TABLE II

Direct Effect of Inactiator on Bacterial Chemotactic Factor

\begin{tabular}{lcrc}
\hline \multicolumn{2}{c}{ Inactivator*added to } & & \\
\hline $\begin{array}{c}\text { cells } \\
\text { (upper) }\end{array}$ & $\begin{array}{c}\text { chemotactic } \\
\text { factor }\end{array}$ & $\begin{array}{c}\text { Chemotactic } \\
\text { value }\end{array}$ & Inhibition \\
\hline$\mu l$ & & 165 & $\%$ \\
10 & - & 180 & 16 \\
20 & - & 190 & 0 \\
50 & - & 25 & 0 \\
- & 10 & 20 & 100 \\
- & 20 & 20 & 100 \\
- & 50 & & 100 \\
- & - & positive control: 190 & - \\
- & - & negative controlł: 30 & - \\
\hline
\end{tabular}

* Soluble ammonium sulfate fraction $(45 \%)$ of normal human serum, dialized and concentrated to 3 times the original volume of serum. The inactivator was incubated for $30 \mathrm{~min}$ at room temperature with either cells or bacterial chemotactic factor before the chemotactic assay.

$\ddagger$ Hank's medium.

strength 0.05 ) before being tested for their ability to inhibit chemotactic activity.

Salt fractionation. Normal human serum was allowed to clot for $2 \mathrm{~h}$ and then precipitated with ammonium sulfate at 40 or $45 \%$ saturation at $5^{\circ} \mathrm{C}$. (No differences in yield or behavior of the chemotactic factor inactivator were noted uncler these two conditions of fractionation.) The supernate was then dialyzed for $48 \mathrm{~h}$ against phosphate-buffered saline. Unless otherwise indicated, the dialyzed fractions were concentrated with PM-10 membrane (Amicon Corp., Lexington, Mass.) to one-third the original volume of serum before assaying for chemotactic inactivator activity.

Ultracentrifugation and gel chromatography. Ultracentrifugal characteristics of various preparations were determined by fractionation in a sucrose density gradient (7.5-

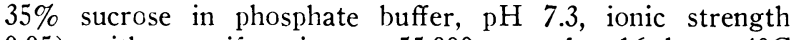
0.05 ) with centrifugation at $55,000 \mathrm{rpm}$ for $16 \mathrm{~h}$ at $4^{\circ} \mathrm{C}$ in an International Hematocrit Centrifuge (International Equipment Co., Boston, Mass.), B-60 using a swinging bucket rotor (4). Gel chromatography was carried out with Biogel P200 (Bio-Rad Laboratories, Richmond, Calif.) in phosphate-buffered saline. The proteins human IgG, BSA, and cytochrome $c$ were used as markers in ultracentrifugal and gel filtration techniques. The same markers have been used previously (7).

\section{RESULTS}

Salt fractionation of chemotactic factor inactivator. When the bacterial factor from $E$. coli was treated with $100 \mu 1$ whole human serum no significant loss of chemotactic activity was noted (Table I). At the present time at least 20 different whole normal human sera have been tested and found to be lacking in ability to inhibit chemotactic activity. However, when the various ammonium sulfate fractions from each of two sera were studied, it was found that the soluble fraction of serum was sig- 


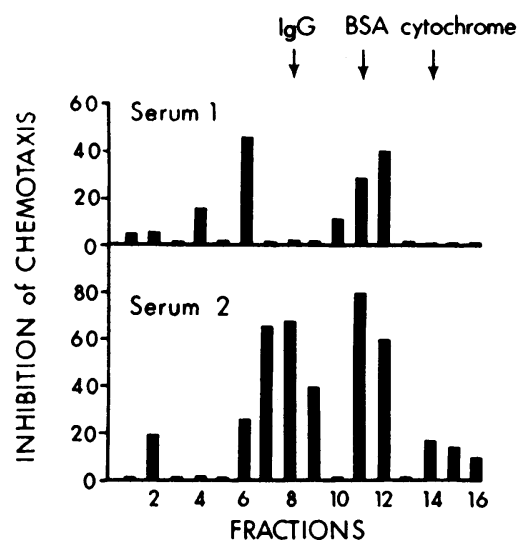

FIgURE 1 Patterns of chemotactic factor inactivator in ammonium sulfate-soluble fractions from two normal human sera, separated by density gradient ultracentrifugation. 50 $\mu 1$ bacterial chemotactic factor was incubated with each fraction from the gradients at $25^{\circ} \mathrm{C} \times \frac{1}{2} \mathrm{~h}$, the mixture then assayed for residual chemotactic activity. In each of the preparations two zones of inhibitor are present.

nificantly inhibitory for the chemotactic factors when appropriate volumes were used. No inhibitory activity could be demonstrated in the redissolved precipitate, indicating that the chemotactic factor inactivator is associated with a fraction of serum other than the Ig-rich fraction.

Direct action of inactivator on the chemotactic factor. These experiments were designed to determine if the inactivator was directly affecting the chemotactic factors or the indicator leukocytes. Using the ammonium sulfate soluble (concentrated) fraction from normal serum

TABLE III

Irreversible Effect of Chemotactic Factor Inactivator

\begin{tabular}{|c|c|c|}
\hline Material tested* & $\begin{array}{l}\text { Chemotactic } \\
\text { activity } \ddagger\end{array}$ & c Inhibition $\S$ \\
\hline Blank & 25 & - \\
\hline Bacterial factor & 240 & - \\
\hline Bacterial factor boiled (15 $\mathrm{min})$ & 270 & 0 \\
\hline $\begin{array}{l}\text { Bacterial factor }+ \text { inactivator, } \\
37^{\circ} \mathrm{C} \times 20 \mathrm{~min} \text {, then boiled }(15 \mathrm{~min})\end{array}$ & 100 & 59 \\
\hline $\begin{array}{l}\text { Bacterial factor }+ \text { boiled }(15 \mathrm{~min}) \\
\text { inactivator, } 37^{\circ} \mathrm{C} \times 20 \mathrm{~min}\end{array}$ & 205 & 15 \\
\hline $\begin{array}{l}\text { Boiled }(15 \mathrm{~min}) \text { bacterial factor }+ \text { in- } \\
\text { activator, } 37^{\circ} \mathrm{C} \times 20 \mathrm{~min}\end{array}$ & 90 & 63 \\
\hline
\end{tabular}

* Source of bacterial chemotactic factor was $50 \mu$ l culture supernate (sterilized by filtration) from $E$. coli. Chemotactic factor inactivator was the concentrated and dialized soluble fraction after precipitation of normal human serum with ammonium sulfate at $45 \%$ saturation. A volume of $20 \mu \mathrm{l}$ was used.

$\ddagger$ Counts of migrated cells in five high power fields. $\S$ Per cent. described in Table I, increasing amounts ot this material were added either to the leukocyte suspension or to the bacterial chemotactic factor and then incubated for 20 min at room temperature. Table II shows the results of these experiments. When $10-50 \mu 1$ inactivator was incubated with cells, no effect on chemotactic activity was noted. However, as little as $10 \mu \mathrm{l}$ inhibitor added directly to the bacterial factor completely eliminated chemotactic activity. These results indicate that the inhibitor present in the $45 \%$ ammonium sulfate soluble fraction of human serum acts directly on the chemotactic factor (rather than on the cells) to render it inactive. When large amounts of inhibitor $(>50 \mu 1)$ were added to the cell suspension, decreased chemotactic responses were found, presumably due to an effect of the inhibitor on the diffusing chemotactic factor.

Irreversible nature of the chemotactic factor inhibitor. The inactivator (described above) was mixed with the bacterial chemotactic factor under a variety of conditions. Bacterial chemotactic factor boiled for $15 \mathrm{~min}$ showed no loss of activity (Table III). When the inactivator was added to the boiled bacterial chemotactic factor, $63 \%$ loss of chemotactic activity resulted. The prior boiling of the inactivator abolished most of the inhibitory effect on chemotactic activity (Table III, 15\% loss), whereas boiling the mixture of inactivator and chemotactic factor (after they had been incubated together) failed to restore the chemotactic activity $(59 \%$ loss). These results indicate that the chemotactic factor inactivator acts in an irreversible manner on the bacterial chemotactic factor to render it inactive.

Broad spectrum of activity of inactivator on chemotactic factors. The previous experiments indicated that the inactivator present in the soluble (and concentrated) fraction of ammonium sulfate-treated human serum could inactivate the bacterial chemotactic factor. The data in Table IV demonstrate that the inactivator has a rather

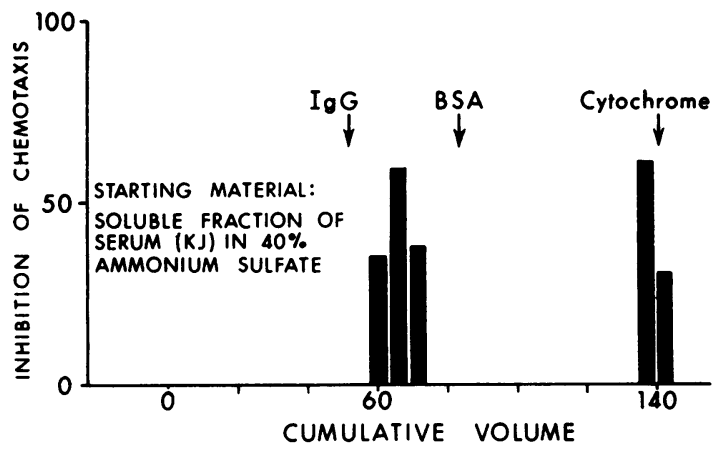

FIGLre 2 Elution from Biogel 200 of the soluble fraction of human serum obtained with ammonium sulfate at $45 \%$ saturation. From each sample $100 \mu \mathrm{l}$ volumes were incubated with $50 \mu \mathrm{l}$ bacterial chemotactic factor at $25^{\circ} \mathrm{C} \times \frac{1}{2} \mathrm{~h}$, then assayed for residual chemotactic activity. Two zones of inhibitor are present. Protein was measured in the Folin reaction. 
broad range of activity on chemotactic factors. The chemotactic activity of human serum, treated with zymosan (4), the complement-derived chemotactic factor $\mathrm{C} \overline{567}$ and the chemotactic fragments of $\mathrm{C} 3$ and $\mathrm{C} 5$, and the $E$. coli bacterial factor were all inhibited. Thus, the chemotactic inactivator obtained from human serum is able to inactivate both complement-derived and complement-independent chemotactic factors. Reasons for the different degrees of inactivation (59-96\%, Table IV) of various chemotactic factors are not known at the present time.

Ultracentrifugal analysis of chemotactic factor inactiz'ator. Sucrose density gradient ultracentrifugation was performed to determine physical-chemical characteristics of the chemotactic factor inactivator. Two inhibitor-rich preparations, threefold concentrates of ammonium sulfate-soluble fractions, as described above, from two different human sera were studied. The results are shown in Fig. 1. For these experiments $50 \mu 1$ bacterial chemotactic factor was added to each of the 16 fractions from the density gradients incubated for $\frac{1}{2} \mathrm{~h}$ at room temperature, then diluted to $1 \mathrm{ml}$ in Hank's medium and tested for residual chemotactic activity. Both frames in Fig. 1 indicate that inactivator activity is biphasic, appearing at or below the IgG marker, and near the albumin (BSA) marker. These results suggest that the chemotactic factor inactivator in serum is heterogenous and can be resolved into at least two different fractions.

Isolation of chemotactic factor inactiz'ator by molecular sieving. The inactivator-rich fraction of serum produced by ammonium sulfate treatment was chromatographed in Biogel-200 (Bio-Rad Laboratories) at $\mathrm{pH}$ 7.3 (Fig. 2). Two zones of inhibitor activity were demonstrated: the first eluted between the IgG and BSA markers, and the second near the cytochrome c marker. As with the ultracentrifugal fractionation, these data indicate a heterogeneity in the characteristics of the chemotactic factor inactivator. In experiments not listed here rechromatography of each of the two zones of chemotactic factor inactivator has resulted in the same chromatographic position of each inactivator as in the original separation. This finding together with those to be presented below suggests that the heterogeneity of the inactivator is due to two separate and distinct substances.

Electrophoretic separation of the inactivator. $8 \mathrm{ml}$ normal human serum not previously fractionated was electrophoresed in a Pevikon block at $\mathrm{pH} 8.6$ and the fractions $(100 \mathrm{ml}$ each) tested for ability to inhibit the bacterial chemotactic factor was found to be present in two zones corresponding to $\alpha$ - and $\beta$-globulin positions. (Fig. 3). To what extent these two zones of inactivator relate to the two zones found by ultracentrifugation and gel filtration (Figs. 1 and 2) is not known.

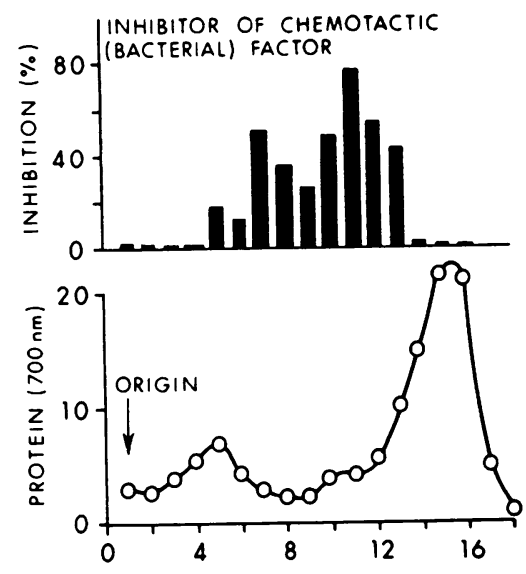

FIGIRE 3 Electrophoretic separation of normal human serum in Pevikon, $\mathrm{pH}$ 8.6, barbital buffer, ionic strength 0.05 . Detection of inactivator was carried out, as described in Fig. 2. Two zones of inhibitor are present, one in the $\beta$-position, the other in the $\alpha$-position towards the anode (to right).

Mechanisms of action of chemotactic factor inactivator. None of the preceding experiments defined the mechanism by which the inactivator interacts with chemotactic factors to render them inactive. To study this question, the trypsin produced (and radio-labeled) C5 fragment was isolated and then incubated with the inactivator. The source of the inactivator was the material eluting near the IgG marker from a Biogel column (Fig. 2). This inactivator was concentrated to a volume of one-third the original serum volume. $10 \mu 1$ inactivator was incubated with $50 \mu \mathrm{l}$ C5 fragment (equivalent to approximately $5 \mu \mathrm{g}$ original $(5)$ at room temperature for $20 \mathrm{~min}$, and then ultracentrifuged. The results are seen in Fig. 4. Neither the amounts of radioactivity in the gradient nor the position of the radioactivity seemed

TABLE IV

Inactication of Seceral Chemotactic Factors by Inacticator

\begin{tabular}{|c|c|c|c|}
\hline \multirow[b]{2}{*}{ Factor tested } & \multicolumn{2}{|c|}{ Chemotactic activity } & \multirow[b]{2}{*}{ Inhibition } \\
\hline & $\begin{array}{l}\text { Inhibitor } \\
\text { absent }\end{array}$ & $\begin{array}{l}\text { Inhibitor } \\
\text { present }\end{array}$ & \\
\hline & & & 30 \\
\hline Activated serum* & 2000 & 5 & 96 \\
\hline C $\overline{567}(5 \mu \mathrm{g})$ & 280 & 30 & 89 \\
\hline C3 fragment + & 145 & 35 & 59 \\
\hline C5 fragment $\ddagger$ & 280 & 100 & 65 \\
\hline $\begin{array}{l}\text { Bacterial factor } \\
\quad(50 \mu \mathrm{l}, \text { from } E \text {. coli })\end{array}$ & 250 & 90 & 64 \\
\hline
\end{tabular}

* One-tenth human serum incubated with $1 \mathrm{mg}$ zymosan (4). In all experiments $20 \mu \mathrm{l}$ inhibitor was used.

$¥ 50 \mu \mathrm{g}$ C3 or C5 chemotactically activated with trypsin. (See text). 


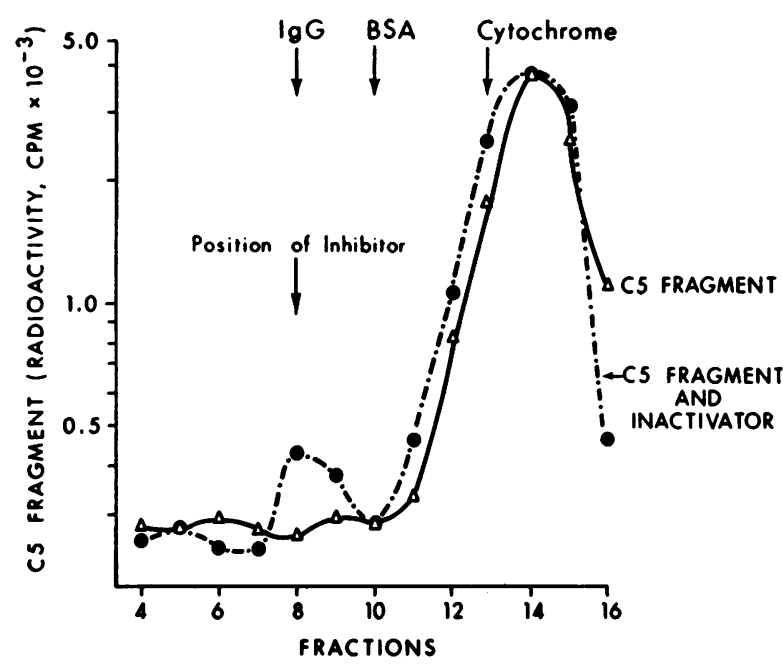

FIgURe 4 Sucrose density gradient analysis by ultracentrifugation of radio-tagged and chemotactically active C5 fragment before (solid line) and after (dotted line) treatment with inhibitor isolated in Fig. 2 (the inactivator used was the one that eluted near the IgG marker). The inactivator does not cause a shift in the main peak of radioactivity of the C5 fragment.

altered as a result of inactivation (Fig. 4 , broken line), when compared with the pattern for the untreated chemotactic fragment (Fig. 4, solid line). Chemotactic tests of the various fractions showed the presence of high levels of activity in fractions 12-14 (Table V), whereas chemotactic activity in the same fractions was lost as a result of pretreatment of the $\mathrm{C} 5$ fragment with the inactivator (Table V). It should be pointed out that in the preparation of $\mathrm{C} 5$ fragment treated with the inactivator a small zone of radioactivity was seen in the ultracentrifugal position of the inactivator (Fig. 4, fractions 8 and 9). The significance of the small amount of radioactivity $(\sim 4 \%$ of total radioactivity in the $\mathrm{C} 5$ fragment preparation) is unknown. While we cannot rule out a highly reversible interaction, these data suggest that however the inactivator alters the C5 fragment it is probably not due to substantial, irreversible binding to the chemotactic factor.

\section{DISCUSSION}

The data presented in this paper indicate that there exists in normal human serum an inactivator of chemotactic factors. This inactivator is heterogenous in that, by a variety of fractionation techniques, the material appears in two positions. The chemotactic factor inactivator acts directly and irreversibly on the chemotactic factor, and it has a broad spectrum of activity, inactivating $\mathrm{C} \overline{567}$, the chemotactic fragments of $\mathrm{C} 3$ and $\mathrm{C} 5$, and the bacterial chemotactic factor derived from E. coli. It is not possible to completely exclude the pos- sibility that some of the effect of the chemotactic factor inactivator is cell-directed, but the bulk of the evidence from these studies strongly suggests otherwise. It should be noted that normal human serum contains this inactivator, but the amount present is usually too low to detect in the absence of any fractionation and/or concentration procedures. These would explain why it is possible to chemotactically activate normal human serum with agents that trigger the complement system, in spite of the fact that chemotactic factor inactivator exists in the serum.

The mechanism by which the inactivator interacts with the chemotactic factor is not precisely known. The data in Fig. 4 and Table $\mathrm{V}$ do not permit an unambiguous conclusion regarding the mechanism by which the chemotactic factor inactivator abolishes the chemotactic activity. It can be clearly stated that this is through a direct effect on the chemotactic factor rather than by an effect on leukocytes.

If the mechanism of inactivation of the chemotactic factors is indeed enzymatic, then the broad spectrum of action by the chemotactic factor inactivator may imply a common functional and structural region in each of the chemotactic factors. There may be an analogy in previous chemotactic studies where it was demonstrated that deactivation of leukocytes by way of complement chemotactic factors eliminates subsequent chemotactic responsiveness to any of the complement-derived or the bacterial (E. coli) chemoattractants (10). This could be interpreted to indicate a common receptor on the neutrophil for structurally different factors, or it could also indicate structurally similar chemotactic factors all acting on the same receptor. In the latter context, the

TABLE V

Chemotactic Activity in C5 Fragment*

\begin{tabular}{|c|c|c|c|}
\hline \multirow{2}{*}{$\begin{array}{c}\text { Fraction } \\
\text { tested } \\
(25 \mu \mathrm{l})\end{array}$} & \multicolumn{2}{|c|}{$\begin{array}{l}\text { Chemotactic activity in ultra- } \\
\text { centrifugal fractions. }\end{array}$} & \multirow{2}{*}{$\begin{array}{l}\text { Loss of } \\
\text { chemotactic } \\
\text { activity }\end{array}$} \\
\hline & $\begin{array}{l}\text { fragment } \\
\text { untreated }\end{array}$ & $\begin{array}{c}\text { fragment } \\
\text { treated } \ddagger\end{array}$ & \\
\hline & & & $\%$ \\
\hline 12 & 110 & 20 & 82 \\
\hline 13 & 160 & 40 & 75 \\
\hline 14 & 165 & 65 & 61 \\
\hline 15 & 20 & 30 & 0 \\
\hline
\end{tabular}

* Obtained by isolation of trypsin treated C5. $5 \mu \mathrm{g} \mathrm{C5} \mathrm{frag-}$ ment were fractionated in each of two gradients.

$\ddagger$ The chemotactically active C5 fragment from $5 \mu \mathrm{g}$ (volume of $50 \mu \mathrm{l}$ ) was incubated with $10 \mu \mathrm{l}$ (approximately $25 \mu \mathrm{g}$ protein) of inhibitor-rich fraction of serum. After incubation at $37^{\circ} \mathrm{C} \times 20 \mathrm{~min}$, ultracentrifugal separation, shown in Fig. 2, was performed. Chemotactic activity in various fractions from each of two gradients was then assessed. 
broad activity of the chemotactic factor inactivator would be readily explicable.

It is not surprising that in human serum there should exist an inactivator of chemotactic factors, whether these be products of intrinsic proteins such as complement, or products of extrinsic agents such as bacteria. In the cases of the kinins and anaphylatoxins, potent inhibitors present in serum inactivate these biologically active peptides in an irreversible and enzymatic manner $(2,11)$. Other inhibitors such as the C-1 inhibitor (12), $\alpha_{2}$-macroglobulin (13) and $\alpha_{1}$-antitrypsin (14) exert a regulatory function by stoichometric-binding with a number of enzymes, resulting in their inactivation, thereby limiting the action of kinin-producing, fibrinolytic, complement and coagulation pathways. $\alpha_{1}$-antitrypsin also inactivates the neutrophil-derived neutral protease and elastase (15), providing a control mechanism to prevent undue destruction of tissue proteases by leukocytic enzymes. It would be anticipated that active substances such as the chemotactic factors would fall under similar control, otherwise one would predict uncontrolled mobilization of leukocytes into foci containing chemotactic factors.

A major question arising from these studies concerns the relationship of the inhibitor of chemotactic factors and the anaphylatoxin inactivator (AI) ${ }^{1}$ described by Bokisch et al. (2). AI is a pseudoglobin with an electrophoretic mobility of an $\alpha$-globulin, a molecular weight of 325,000 , and is present in normal human serum. This inactivator has carboxypeptidase $\mathrm{B}$ activity and largely accounts for the ability of normal human serum to rapidly destroy the kinins generated by kallikrein and the anaphylatoxin peptides $\mathrm{C} 3 \mathrm{a}$ and $\mathrm{C} 5 \mathrm{a}$. To what extent are $\mathrm{AI}$ and the inactivator of chemotactic factor identical? On the basis of the data presented in this paper there are some similarities between the two inhibitors. On the other hand, there are several significant differences. As shown by ultracentrifugal, electrophoretic, and molecular sieving techniques, the chemotactic factor inhibitor is heterogenous, consisting of two different substances. Bokisch et al. (2) described a single form of AI in serum, but later work has revealed that AI may exist in serum as a polymer, raising the possibility that under different conditions AI may have variable physical features (16). Evidence to date indicates that the chemotactic factor inactivator is not impaired in the presence of phenanthroline at $10^{-2} \mathrm{M}$. Such results would suggest that the chemotactic factor inactivator is not identical with AI (2). The resolution of the basic question about identity or nonidentity of $\mathrm{AI}$ and the chemotactic factor inactivator must await availability

\footnotetext{
${ }^{1}$ Abbreviation used in this paper: AI, anaphylatoxin inactivator.
}

of a highly purified preparation of the latter. In part, the difficulty in resolving this question relates to the unknown chemical relationship between the chemotactic peptides of $\mathrm{C} 3$ and $\mathrm{C} 5$ and the homologous anaphylatoxins, C3a and C5a. There is highly suggestive evidence in favor of the nonidentity of the homologous peptides with anaphylatoxin and chemotactic function. Although treatment of purified C3 and C5 with trypsin leads to the production of fragments with anaphylatoxin and chemotactic activity, continued treatment with trypsin results in the disappearance of anaphylatoxin, whereas there is no demonstrable loss in chemotactic activity $(17,18)$. Since there is a fundamental question regarding structure relationship between the anaphylatoxins and the chemotactic factors, extrapolations between the data from $\mathrm{AI}$ and those of the chemotactic factor inactivator are difficult. Furthermore, it should be pointed out that while human serum cannot be activated to produce anaphylatoxin $(2,17)$, there is little difficulty in activating human serum with an immune complex so as to generate chemotactic activity $(3,4)$. These findings indicate that chemotactic activity which is generated in human serum by complement activating substances is resistant to the effects of inactivators naturally present in serum, either because the chemotactic factors are not susceptible to the inactivators, or because they are generated in quantities too great to be handled by the levels of inactivators. Whatever the case may be, the ability to generate chemotactic activity in human serum certainly stands in sharp contrast to that inability to generate anaphylatoxin activity in whole human serum. It should be stressed that, while some obvious differences exist between $\mathrm{AI}$ and the serum inhibitor of chemotactic factors, as revealed by fractionation procedures, there is no definitive answer to the question of identity or nonidentity of the two inactivators. Perhaps the most relevant point in our data is the demonstration of a naturally occurring chemotactic factor inactivator in human serum. Data will be presented in a subsequent paper to show the presence of this inactivator in super-normal amounts in pathologic human sera.

The problem of a better assay for the chemotactic factor inactivator is obvious. When the inactivator is sufficiently purified, it should be feasible to develop an immunochemical assay that would allow detection of the inactivator in whole serum. Alternatively, when the structural definitions of the various chemotactic factors are obtained, it is possible that this information can be translated into chemical changes in the chemotactic factors reflecting the action of the chemotactic factor inactivator. For the present, however, the functional assay will remain. 


\section{ACKNOWLEDGMENTS}

This paper was supported in part by National Institutes of Health Grant AI 09651-02.

\section{REFERENCES}

1. Ward, P. A. 1970. Neutrophil chemotactic factors and related clinical disorders. Arthritis Rheum. 13: 181.

2. Bokisch, V. A., and H. J. Müller-Eberhard. 1970. Anaphylatoxin inactivator of human plasma: its isolation and characterization as a carboxypeptidase. J. Clin. Invest. 49: 2427.

3. Ward, P. A., C. G. Cochrane, and H. J. Müller-Eberhard. 1965. The role of serum complement in chemotaxis of leukocytes in vitro. J. Exp. Med. 122: 327.

4. Ward, P. A., C. G. Cochrane, and H. J. Müller-Eberhard. 1966. Further studies on the chemotactic factor of complement and its formation in vivo. Immunology. 11: 141.

5. Ward, P. A., I. H. Lepow, and L. J. Newman. 1968. Bacterial factors chemotactic for polymorphonuclear leukocytes. Am. J. Pathol. 52: 725.

6. Nilsson, U. R., and H. J. Müller-Eberhard. 1965. Isolation of $\beta$ if-globulin from human serum and its characterization as the fifth component of complement. $J$. Exp. Med. 122: 277.

7. Ward, P. A., and L. J. Newman. 1969. A neutrophil chemotastic factor from human $C^{\prime} 5$. J. Immunol. 102: 93.

8. Arroyave, C. M. 1972. Interaction between C5, C6 and C7. Fed. Proc. 31 : 659. (Abstr.)
9. Müller-Eberhard, H. J., A. P. Dalmasso, and M. A. Calcott. 1966. The reaction mechanism of $\beta$ ic-globulin $\mathrm{C}^{\prime} 3$ ) in immune hemolysis. J. Exp. Med. 123: 33.

10. Ward, P. A. 1970. Complement derived chemotactic factors and their interactions with neutrophilic granulocytes. Int. Arch. Allergy Appl. Immunol. 108.

11. Erdös, E. G. 1966. Hypotensive peptides: bradykinin, kallkdin, and eledoisin. Adv. Pharmacol. 4: 1.

12. Austin, K. F. 1971. Chemical mediators of the acute inflammatory response. In Progress in Immunology. B. Amos, editor. Academic Press Inc. 724.

13. Ganrot, P. O. 1967. Interaction of plasmin and trypsin with $\alpha_{2}$-macroglobulin. Acta Chem. Scand. 21: 602 .

14. Laurell, C. B., and S. Erickson. 1963. The electrophoretic $\alpha_{1}$-globulin pattern of serum in $\alpha_{1}$-antitrypsin deficiency. Scand. J. Clin. Invest. 15: 132.

15. Janoff, A. 1972. Neutrophil proteases in inflammation. Anmu. Rev. Med. 23: 177.

16. Müller-Eberhard, H. J., V. A. Bokisch, and D. B. Budzko. 1970. Studies of human anaphylatoxins and of their physiological control mechanism. In Immunopathology, VIth International Symposium (Grindelwald). P. A. Miescher, editor. Grune and Stratton, Inc., New York. 191.

17. Cochrane, C. G., and H. J. Müller-Eberhard. 1968. The derivation of two distinct anaphylatoxin activities from the third and fifth components of human complement. J. Exp. Med. $127: 371$

18. Ward, P. A., and J. H. Hill. 1970. C5 chemotactic fragments produced by an enzyme in lysosomal granules of neutrophils. J. Immunol. $104: 535$. 